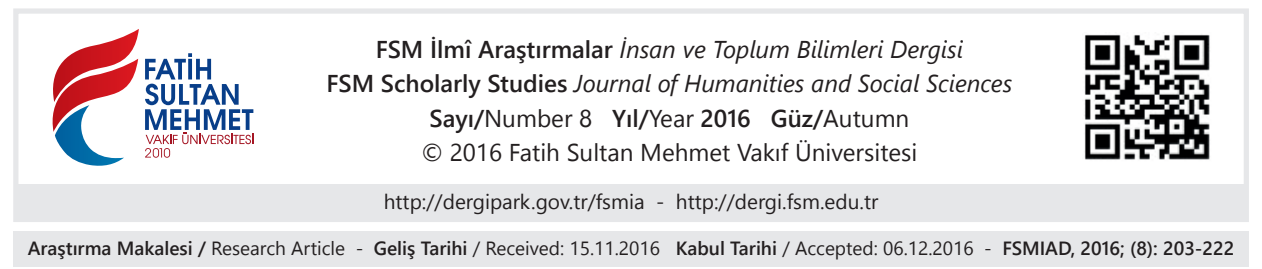

\title{
Mehmed Âkif Ersoy, Necip Fazıl Kısakürek ve Sezai Karakoç Şiirlerinde Bir Medeniyet Öncüsü Olarak Hz. Muhammed
}

Mesut Koçak*

\section{$\ddot{O} \mathbf{z}$}

Bu çalışmada, modern Türk şiirinde farklı edebi dönemlerde ve farklı edebi anlayışlarda eser vermelerine karşın, aynı dünya görüşüne bağlı olmaları sebebiyle, benzer temalar üzerinde durmuş Mehmed Âkif Ersoy, Necip Fazıl Kısakürek ve Sezai Karakoç'un şiirlerinde İslam medeniyetinin öncüsü olarak Hz. Muhammed imgesinin yansıması incelenmiştir. Sadece Türk şiirinin değil, Türk düşüncesinin de en önemli isimleri arasında yer alan bu üç ismin İslam medeniyetine dair algılarında Hz. Muhammed'in tuttuğu yer belirlenmeye çalışılmıştır. Mukayeseli bir yaklaşımla irdelenen konunun, bu üç ismin şiirlerinde hangi derecede ve yoğunlukta yer aldığı ortaya çıkarılmaya çalışılmıştır. Çalışmada temel kaynak olarak üç ismin şiirleri alınmış, somutlaştırma ve pekiştirme adına kısmen düşünce eserlerinden de yararlanılmıştır.

Anahtar Kelimeler: Mehmed Âkif Ersoy, Necip Fazıl Kısakürek, Sezai Karakoç, medeniyet, Hz. Muhammed.

\section{The Prophet Muhammed as a Founder of Civilization in the Poems of Mehmed Âkif Ersoy, Necip Fazıl Kısakürek and Sezai Karakoç}

\section{Abstract}

In this study, the reflection of the Prophet Muhammed's image as a founder of Islamic civilization in the poems of Mehmed Âkif Ersoy, Necip Fazil Kısakürek and Sezai Karakoç, who put emphasis on similar themes thanks to their affiliation with the same world view, although they produced works in different literary periods and different literary understandings in modern Turkish poetry, has been studied. It has been tried to determine the role of the Prophet Muhammed in the perceptions of Islamic civilization on those three names who are the most important names of not only Turkish poetry but also Turkish thought. It has been tried to find out the degree and intensity of the theme in the poems of those three names. In this study, the poems of those three names have been taken as the main sources, and some works of thought have been used for reification and emphasis.

Keywords: Mehmed Âkif Ersoy, Necip Fazıl Kısakürek, Sezai Karakoç, civilization, The Prophet Muhammed.

* Arş. Gör., Fatih Sultan Mehmet Vakıf Üniversitesi Edebiyat Fakültesi Türk Dili ve Edebiyatı Bölümü, İstanbul/Türkiye mkocak@fsm.edu.tr 


\section{Giriş}

Sadık Rifat Paşa, 1838'lerde civilisation kavramını tarif etmeye çalışırken kullandığı "usûl-i me'nûsiyet ve medeniyyet" tamlamasındaki medeniyet kelimesinin sonraki yıllarda tarihten uluslararası ilişkilere, teolojiden siyaset bilimine pek çok alanda popüler bir kavram olacağını tahmin etmiş miydi bunu bilmek mümkün değil. Bununla birlikte, Arapça müdûn köküne dayanan ve medîne isminden türetilen medeniyet kelimesinin tam manasiyla civilisation' in yerine kullanımı 1860'lardan sonra olmuştur. Tanımlanması ve çerçevelenmesi en güç kavramlardan biri olan medeniyet, Braudel'in de vurguladığı gibi farklı disiplinlere ve önceliklere göre tanımı değişen bir kavramdır ve aslına bakılırsa hem maddi hem manevi değerleri işaret etmektedir. Örneğin, Karl Marx medeniyetle ilgili olarak altyapılar (maddi) üstyapılar (manevi) ayrımı yaparken, Charles Seignobos biraz da şakayla bu kavram hakkında "uygarlık, yollar, limanlar ve rıhtımlardır" der. Marcel Mauss, uygarlığı "insanlığın tüm kazanımları" olarak niteler ve Eugene Cavaignac, "bilim, sanat, düzen ve erdemlerin minimumudur" tanımlamasinda bulunur. ${ }^{1}$

Kavramın yatay çok yönlülügüüyle birlikte ikinci bir yönü ise dikey katmanl1lığıdır. Bu hususta Will Durant'ın tespitleri önemlidir. Medeniyetin kültürel yaratmayı harekete geçiren sosyal bir düzen olduğunu belirten Durant, ${ }^{2}$ kavramın aynı zamanda toplumsal düzene bağl1, sosyal, siyasi, ekonomik, ahlaki, estetik değerlerden, yeni ve sürekli değerler üretmek olduğunun altını çizer. Ona göre medeniyetin "ekonomik", "siyasi", "ahlaki" ve "zihni" olmak üzere dört şart1 vardır. Medeniyet için gerekli olan bu şartlar, aslında tüm toplumları ilgilendirir. $\mathrm{Bu}$ bağlamda medeniyet, insan tözünü ilgilendiren unsurların etkili olduğu bir alandır. Ekonomik şart; yerleşik hayatı ifade eden ziraata, üretimi ifade eden sanayiye ve mesleki grupları ve paylaşımı ifade eden ekonomik organizasyona dayanır. Siyasi şartın temelinde ise sosyal düzeni koruma işini yüklenen hükümet, düzenin vazgeçilmez dayanağı ve iç güvenlik fikrinin kaynağ1 olan devlet, sözlü geleneklerin yerini alan, bir nevi toplumsal sözleşme olan kanun ve sosyal organizasyonda sanayiyi yeniden düzenleme ve nesli devam ettirme görevini üstlenen aile vardır. Evlilik, din, sosyal ahlak ve cinsel ahlak ise medeniyetin ahlaki şartlarını oluşturur. Durant, evlilik olmadan ailenin olamayacağını, dolayısıyla medeni toplumun temeli için evliliğin şart olduğunu ifade eder. Ahlak ise, parçanın bütünle ve her grubun daha büyük bir grupla işbirliğine girmesi demektir ve medeniyet için bu işbirliği olmazsa olmazdır. Medeniyetin zihni şartları ise edebiyat, bilim ve sanata dayanır. Kelimelerle düşünce arasındaki ilişki, alet ile yapılacak

1 Fernand Braudel, Uygarlıkların Grameri, (Çev.: Mehmet Ali Kilıçbay), İstanbul, İmge Kitabevi, 1996, s. 29.

2 Will Durant, Medeniyetin Temelleri, (Çev: Nejat Muallimoğlu), İstanbul, Erguvan Yayınevi, 2007, s. 15. 
iş arasındaki ilişkiye benzer. Yazı medeniyetin en önemli işaretidir. Edebiyat da yazının var olduğu toplumlarda vücut bulur ve ilgi görür. Bilim ve sanat da medeniyetin olmazsa olmaz iki unsurudur. Zira ilkel toplumlardan medeni toplumları ayıran en önemli alametifarikalardan ikisinin bilim ve sanat olduğunu belirtir. ${ }^{3}$

Durant'n tespitlerindeki iki husus, daha sonraki y1llarda medeniyet üzerine düşünce üreten yazarlarda farklı cepheleriyle ve Durant'a göre daha fazla önem atfedilerek işlenmiştir. Bu bağlamda Braudel'in düşüncelerinden hareketle bu iki hususun biraz daha tartışılması faydalı olacaktır. Bu iki husustan birincisi, Durant'ın ifade ettiği "ekonomik", "siyasi", "ahlaki" ve "zihni" şartların doğrudan toplumla ilişkili olmasıdır. Aslına bakılırsa toplumla ilişkili olan bu şartlardan da öte kavramın bizatihi kendisidir ki, Durant buna hiç değinmez. Levi Strauss, bu iki kavram hakkında "aynı nesneye ilişkin tamamlayıcı iki perspektife tekabül eder" derken, kavramın sadece insaniliğine işaret etmekle kalmaz, farkında olarak ya da olmayarak onu insanla ilgili olan her şeye bağlamış olur. Braudel de "Uygarlıklar toplumlardır" yargisında bulunurken, hem toplum kavramının hem uygarlık kavramının aynı gerçekliğe ilişkin olduğunun altını çizer. Bir başka deyişle medeniyet olmadan toplumlar ilkel, toplumlar olmadan medeniyet ise imkânsızdır. Bunu Batı medeniyeti örneği ile somutlaştıran Braudel, bu medeniyetin, ona can veren "endüstriyel toplum"a bağımlı olduğunu belirtir. Bu toplumun grupları, gerilimleri, entelektüel ve ahlaki değerleri, idealleri, zevkleri vs. Batı medeniyetine taalluk etmekte, onu resmetmektedir. ${ }^{5}$ Durant' 1 medeniyetin şartları ile ilgili tasnifinde tartışılması gereken ikinci husus ise, ahlakın aslında medeniyetin diğer şartları üzerinde belirleyici, tayin edici, yönlendirici hatta kurucu unsur olmasıdır ki, bunda en önemli âmil, ahlakın özünde dini barındırmasıdır. Durant' 'n dini ayrı bir ana katman olarak değil de ahlakın içinde tali bir unsur olarak tasnife dâhil etmesi, başarılı ve kapsayıcı denebilecek tasnifini zayıflatmıştır demek yanlış olmaz. Zira medeniyetler aynı zamanda ortak zihniyetlerden doğar ve bu ortak zihniyet, çoğunlukla bir inanç, korku ve endişenin mirası olarak belirir. Ortak zihniyet tohumları kuşaktan kuşağa aktarılan bir aşılanmanın ürünüdür. Medeniyetlerin, özellikle de Batı-dışı medeniyetlerin, kalbinde ve zihninde hem bir geçmiş hem de şimdi olarak yer tutan din, en güçlü çizgiyi oluşturur. ${ }^{6}$ Dolay1sıyla Durant -belki de bilinçli bir tercihle- kökü dal yapmış, dinin medeniyet üzerindeki başat belirleyiciliğini, ahlak vasıtasına bağlama yoluna gitmiştir.

Nasıl tanımlanırsa tanımlansın, neyle ilişkilendirilirse ilişkilendirilsin görülüyor ki, medeniyet, onu meydana getiren, başka deyişle içinden çıktığı toplumun zihniyetinden bağımsız değerlendirilemez. Batı'da antik çağda tanrısız ve pagan

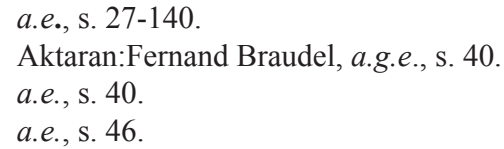


bir alg1 üzerine inşa edilmeye çalışılan medeniyet, Ortaçağda Hıristiyan ahlak1nın ve şeriatının üzerine kurulmaya başlanır. Aydınlanma ve moderniteyle birlikte -elbette Avrupa kıtasının kendi içinde yaşadığı büyük mücadele tecrübesini de eklemeliyiz- Hıristiyanlık gücünü kaybeder ve tanrı yerini insana, insan aklına, kısacası seküler bir medeniyet algısına bırakır. Mesele dünyayı ve evreni yorumlayışla ilgilidir aslında. İslam medeniyeti için de durum farklı değildir. İslam medeniyeti ilk İslam şehri olarak kurulan Medine'den, Abbasilere, oradan Endülüs ve Osmanlı'ya uzanır. İslam medeniyeti, İslam dininin şeriat ve ahlak anlayışına koşut yaşamanın bir sonucu olarak ortaya çıkar ve zamana ve coğrafyaya bağlı kültürel farklılıklara rağmen, belli bir dünya görüşü, bir varlık anlayışı ve zihniyeti ifade edecek şekilde günümüze kadar gelir.? Tam da burada Braudel'in “Uygarlıklar sürekliliklerdir" $"$ tespiti hatırlanmalıdır. Braudel, bu süreklilik içinde bazı dönemlerin ve durumların, o medeniyetin tarihinde önemli bazı olayların ve istisnai kişilerin sahip oldukları müstesna yeri anlamaya yardımcı olduğunu vurgular. Örneğin Dante ve Geothe gibi sanatçılar, Newton ve Einstein gibi bilim insanları, Sokrates, Platon ya da Descartes gibi büyük düşünce sistemlerinin kurucuları aynı zamanda birer medeniyet kurucularıdır. Bunların da ötesinde medeniyetlerin tarihleri içinde konjonktüre yenilmeden, geçmişten bugüne güçlü birer figür olarak gelmiş, hatta kendi şahsiyetlerini aşarak ilgili uygarlığın sembolü olmuş, Braudel'in "büyük dinlerin kurucuları" olarak nitelediği şahsiyetler de birer medeniyet kurucularıdır. Bu bağlamda o, İslam medeniyetinin kurucusu olarak da Hz. Muhammed'i gösterir. ${ }^{9}$

Braudel'in Hz. Muhammed'i İslam medeniyetinin kurucusu olarak tavsif etmesi, bir yönüyle medeniyet kavramının tarihiyle ilişkilidir demek yanlış olmaz. Zira yirminci yüzyıla ait bu vasıflandırmanın önceki yüzyıllarda yapılmadığı görülmektedir. İlahiyat, tarih ve sanat gibi farklı alanlardaki klasik kaynaklara bakıldığında Hz. Muhammed genellikle İslam dininin peygamberi, dolayısıyla kurucusu, Müslümanların önderi, lideri gibi sıfatlarla anılmış, daima bu yönleri ile irdelenmiş ya da eserlere konu edilmiştir. Ancak önce Batı medeniyeti karş1sında İslam'ın da bir medeniyetinin olduğu, daha sonra ise, İslam'ın başlı başına bir medeniyet olduğu görüşüyledir ki, Hz. Muhammed de bu medeniyetin öncüsü ve kurucusu olarak düşünülmeye başlanmıştır. ${ }^{10} \mathrm{Bu}$ bağlamda vasıflandırma dönüşümünün en somut şekilde izlenebileceği alanların başında Türk şiiri gelir.

7 İbrahim Kalın, "Dünya Görüşü, Varlık Tasavvuru ve Düzen Fikri: Medeniyet Kavramına Giriş", Divan Disiplinlerarası Çalışmalar Dergisi, S. 29, 2010, s. 37

8 Fernand Braudel, a.g.e., s. 49.

9 a.e., 52.

10 Batı menşeli civilization kavramını karşılayacak şekilde medeniyetkavramının Osmanlı aydınları tarafından kullanılmaya başlanması ve kavramın Türkçe içindeki gelişimi, bu makalenin de dayanağı olan doktora çalışmamızda detaylı olarak irdelenmiştir. Konuyla ilgili müstakil bir çalışma için ayrıca bakınız: Tuncer Baykara, Osmanlılarda Medeniyet Kavramı ve Ondokuzuncu Yüzyıla Dair Araştırmalar, İzmir, Akademi Kitabevi, 1992 


\section{Türk Şiirinde Hz. Muhammed}

Klasik Türk şiirinde Hz. Muhammed; naat, mevlid, şemâil, hilye, siyer, hicretnâme, mucizât-ı nebî, esmâ-i nebî, regâibiyye, vefâtü'n-neb̂̂, şefaatnâme, kırk hadis gibi türlerle kendisinden en çok söz edilen, hakkında en çok şiir yazılan şahsiyettir. Buna tasavvuf şiirindeki ilahi, nefes vb. türler ile halk şiirindeki koşma ve semaîler eklendiğinde, ciddi bir peygamber edebiyatının varlığından söz edilebilir. ${ }^{11}$ Âmil Çelebioğlu da bu zenginliğe dikkat çekerek, dünyanın hiçbir yerinde bir peygambere, bir din ya da doktrine Hz. Muhammed'e olduğu gibi çeşitli şekil ve türlerde, asırlar sürecek bir sürede müstakil eserler meydana getirilmemiş olduğunu belirtir. Ona göre, genel olarak İslam milletleri, özelde ise Türk milleti bu bağlamda çok zengin bir edebiyata sahiptir. ${ }^{12}$

Türk edebiyatındaki bu zenginlik içinde öyle eserler vardır ki, üzerinden geçen zamana rağmen eskimemiş ve kendi türdeşleri içinde çok daha fazla ön plana çıkmıştır. Türk edebiyatında ilk örneğine on dördüncü yüzyıl şairlerinden Mustafa Darîr'in mensur-manzum karışık Sîretü'n-Nebîadlı eseri olan mevlid türünün en tanınıp bilineni Süleyman Çelebi'nin 1409 yılında tamamladığı Vesîletü'n-Necâta dlı eseridir. Halk içinde kendi özel ismi yerine mevlid olarak adlandırılmış bu eser öyle benimsenmiş ve sahiplenilmiştir ki, halk içinde mevlid geleneği bu eserle sürdürülmüş, sürdürülmeye de devam etmektedir. Bu eserden başka, mevlid türünde en az onun kadar sevilmiş bir başka eser ise Yazıcıoğlu Mehmed'in 1449 yılında tamamladığı Muhammediyye'dir. Bu eser de asırlarca bir başucu kitabı olarak okunmuş, Türk milletinin peygamberine olan sevgi ve muhabbetini beslemiş ve büyütmüştür. Bu eserlerde Mz. Muhammed'in doğumu, çocukluğu, evlenmesi, peygamberliği, mucizeleri, savaşları gibi hayatına dair hususlar manzum olarak anlatılır. Bu eserler bir nevi manzum siyer de sayılabilir. Her ne kadar Hz. Muhammed'in mucizelerine bu tür eserlerde değinilse de müstakil olarak onun mucizelerine dair eserler de yazılmıştır. Mucizât-ı nebî adı verilen bu türde ilk akla gelen örnekon yedinci yüzyıl şairlerinden Ganîzâde Nâdirî'nin $M i$ 'râciyye'sidir. Hz. Muhammed'in dış görünüşü ile ilgili bilgilerin verildiği hilye türünde ise on altıncı yüzyıl şairlerinden Hâkânî Mehmed Bey'in Hilye-i Sa'âdet'i meşhurdur. Bu türlerin dışında Klasik edebiyat içinde kırk hadis türündeki eserler de ciddi bir yekûn tutmaktadır. Kur'an'dan sonra İslam dininin en önemli kaynağ1 olan Hz. Muhammed'in sözlerinin derlendiği bu türde eser veren en bilindik isimler Nâbi ve Fuzulî'dir Ayrıca on beşinci yüzyıl şairlerinden Hatiboğlu'nun Ferahnâmeadlı eseri de ilk manzum kırk hadislerden biridir. ${ }^{13}$

11 M. Fatih And1, "Peygamber'i Şiirle Sevmek-XII: Hazret-i Peygamber'den İstimdâd", Itibar Ayllk Edebiyat ve Fikir Dergisi, Y11: 6, Sayı: 53, Şubat 2016, s. 40.

12 Âmil Çelebioğlu, "Türk Edebiyatında Manzum Dînî Eserler”, Şükrü Elçin Armağanı, Ankara, Hacettepe Üniversitesi Edebiyat Fakültesi, 1983, s. 158.

13 Ahmet Arı, Dîvân Edebiyatında Hazret-i Peygamber, http://www.sonpeygamber.info/downloads/uploads/kutludogum/I/ 19.pdf $(10.09 .2016,19.00)$. 
Klasik Türk şiirinde İslam peygamberini konu edinen bu türler içinde en çok dikkat çekeni naat türüdür. Bir başka deyişle Hz. Muhammed'e duyulan sevginin, saygının, muhabbetin ve bağlılı̆̆ın bir tezahürü olarak divan sahibi olan hemen her şair naat türünde bir eser kaleme almıştır. İslam peygamberini övmek, onu yüceltmek, onun şefaatini istemek gibi nedenlerle kaleme alınan bu türde köklü bir gelenek oluşmuştur. Üstelik bu geleneksel tür, yukarıda sayılan birçok türün aksine, akamete uğramamış, günümüze kadar yazıla gelmiştir.

Klasik Türk şiirinin naat türü bakımından son derece zengin olması bir yana, bu şiir nitelik bakımından da üstün eserleri barındırır. Bunlar içinde özellikle Fuzûlî’nin Su Kasidesi ile Şeyh Gâlib'in "Sultan-1 rûsül şâh-1 mümeccedsin efendim / Bî-çârelere devlet-i sermedsin efendim" mısralarıyla başlayan naatı ve Nâbî'nin "Sakın terk-i edebten kuy-1 Mahbub-i Huda'dır bu / Nazargâh-i ilâhidir, Makam-1 Mustafâdır bu" beytiyle başlayan naatı hem estetik yönden üstünlükleriyle hem de bugüne değin bu türde akla ilk gelenn örnekler olmalarıyla ayrı yeri haizdirler. Bu naat geleneği modern edebiyatta da devam etmiş, Batılılaşmaya rağmen Tanzimat dönemi şairlerinden Cumhuriyet dönemi şairlerine kadar birtakım kırılma ve değişmeler olsa da belli bir çizgide bugüne kadar gelmiştir. Naat türünde modern Türk şiiri de bir hayli zengindir. Tanzimat ve Meşrutiyet y1llarında Ziya Paşa, Namık Kemal, Recaizade Mahmud Ekrem ve Muallim Naci; Cumhuriyet yıllarında Arif Nihat Asya, Nurullah Genç, Bahaeddin Karakoç, Erdem Bayazıt gibi birçok isim naat kaleme almıştır. Bütün bu şiirlerin de geleneğin renklerini barındırdığı söylenebilir. Ancak modern Türk şiirinde üç isim vardır ki, Hz. Muhammed'i Türk şiiri geleneğinden çok daha farklı bir şekilde kendi şiirlerine konu etmişlerdir. Bu isimler, "İslamcı" olarak da nitelenen ve biri söylendiğinde diğerinin ismi hemen akla gelen Mehmed Âkif Ersoy, Necip Fazıl Kısakürek ve Sezai Karakoç'tur. Bu üç ismin Hz. Muhammed'i şiirlerine konu edişleri, anlatışları, bu konudaki niyet ve kasıtları ile onu sembolleştirmeleri Türk edebiyatının diğer şairlerinden daha farklıdır. Onlarda İslam'ın başlı başına bir ideal olmas1 ve İslam peygamberinin bu idealin en önemli unsuru durumunda bulunması bu konuda belirleyicidir denebilir. "Bir dünya görüşü bağlamında, ismi peş peşe zikredilen bu üç düşünce ve sanat adamında, düşünce ve duygu birliği, hedef ve amaç beraberliği, ama aynı idealin farklı şiir dillerinin imkânlarıyla ifadelendirilmesi söz konusudur."14

\section{Mehmed Âkif Ersoy, Necip Fazıl Kısakürek ve Sezai Karakoç Şiirlerin- de Bir Medeniyet Öncüsü Olarak Hz. Muhammed}

Mehmed Âkif Ersoy, Necip Fazıl Kısakürek ve Sezai Karakoç’ta Hz. Muhammed, çok sık gönderme yapıldığı görülür. Öyle ki, dönemi ve çevresi ile birlikte düşünüldügünde bu sıklık, şiirlerinin belirleyici motiflerinden biri haline

14 Turan Karataş, Doğunun Yedinci Ŏglu Sezai Karakoç, Kaynak Kitaplığı, İstanbul 2013, s. $422-$ 423. 
gelir. Bir başka deyişle onların şiirinden Hz. Muhammed ve ona delalet eden unsurlar çıkarıldı ğında şiirlerinde ciddi bir boşluk meydana gelir, birçok şiir hem tema hem de kompozisyon olarak bozulur. Özellikle Âkif'ten Karakoç'a doğru gelindikçe bu ayrılmazlığın, iç içe geçmişliğin derinleştiği görülür. Bunun sebebi ise her üç ismin de Hz. Muhammed'e sadece İslam dinin kurucusu, peygamberi olarak değil, bunlarla beraber sinırları belli bir dünya görüşünün, hayat nizamının, bunlara bağlı bir toplumun ve bu toplumla şekillenen bir medeniyetin kurucusu olarak bakmalarıdır. Bu bakış üç isimde yoğunluk bakımından farklılık göstermekle birlikte önemli bir motiftir.

Mehmed Âkif'in daha 1910 ve 1911 yıllarında mevlid vesilesiyle kaleme aldığ 1 iki şiirinde Hz. Muhammed'e kendinden önceki şairlerin yaklaşımlarından farklı bir niyet ve kasıtla yaklaştığı görülür. Strât-ı Müstakîm'in 81. sayısında yayımlanan "Leyle-i Mevlidü' $n$-Nebî Aleyhisselâm" ve 132. sayısında yayımlanan "Leyle-i Mevlidü'n-Nebî Sallallahu Aleyhi ve Sellem" başlı̆̆ını taşıyan şiirlerde Hz. Muhammed'i doğumu vesilesiyle sadece övmekle yetinmeyen şair, doğrudan İslam âleminin durumunu gündeme getirerek, mevlid' in "Zulmette kalan zemîn- $i$ Şarka" "semâ semâ nûr" saçtığını söyler. İslam âleminin yarınlarının aydınlık ve parlak olmasını bu nûrun devam etmesine bağlayan şair, "Ey leyl devâm edip gideydin: / Ferdâyı da nura kalb edeydin!" misralarıla bitirir bu kisa şiirlerden ilkini. ${ }^{15}$ Bir yıl sonraki mevlid vesilesiyle kaleme aldı̆̆ ikinci şiirde de benzer duygu ve yaklaşımın hâkim olduğu görülür. "On dört asır evvel meşimen senin ey leyl, / Bir nûr-l semâ-pâre doğurmuştu, değil mi??" misralarıyla başlayan şiir, "Yâ Rab, o harîminde yüzen dürr-i yetîmin / Tâhaşre kadar şer'i yetîm olmasin.. Amin!" mısralarıla şiirini noktalar. ${ }^{16}$

Âkif, her iki şiirde de İslâm âleminin karamsar duygular uyandıran haline temas ederek, mevlid zamanı İslam peygamberinin hatırlanmasının bu karamsar havayı bir nebze de olsa dağıttığına işaret eder. Şaire göre yarınların aydınlık olması da ancak Hz. Muhammed'in Müslümanlar tarafından hatırlanmasına bağlıdır. Zira "Ey leyldevâm edip gideydin: / Ferdâyı da nura kalb edeydin!" ifadesi ile beraber düşünüldügünde on dört asır önce doğan "nûr-l semâ-pâre" ile şairin sadece peygamberin zâtını değil, aynı zamanda geleceği yakın olan yeni bir hayatı kast ettiği söylenebilir. Bu hususta en net ve açıklayıcı ifade ise son mısrada saklıdır. Şair, Hz. Muhammed'in yetim oluşuna gönderme ile İslam şeriatının da kıyamete kadar yetim kalmamasının ancak Hz. Muhammed'in, başka bir deyişle onun getirdiği dinin ilkelerinin, hatırlanması ile mümkün olacağını vurgular.

15 Mehmed Âkif Ersoy, “Leyle-i Mevlidü’n-Nebî Aleyhisselâm”, Sırât-ı Müstakîm, Cilt: 4, Say1: 81, 12 Rebîülevvel 328 (24 Mart 1910).

16 Mehmed Âkif Ersoy, "Leyle-i Mevlidü'n-Nebî Sallallahu Aleyhi ve Sellem", Sirât-ı Müstakîm, Cilt: 6, Sayı: 132, 14 Rebîülevvel (16 Mart 1911). 
Mehmed Âkif'in bu kısacık şiirlerle başlayan Hz. Muhammed ve dönemine çağının sosyal ve siyasi şartları içinden, ümmet ve medeniyet perspektifli bakışı sonraki şiirlerinde de derinleşerek devam eder. Örneğin "Mevlid-i Neb̂̂" şiirinde, "Ne lâhûtî geceymişsin ki teksin sermediyyette; / Meşimenden doğan ferdâyahayrânım; ne ferdâdır!' mısralarında açıç̧a görüleceği üzere Hz. Muhammed'in doğumu ile birlikte hayran olunacak yarınlar da doğmuştur. ${ }^{17}$ Burada kast edilen İslam medeniyetidir. Ona göre İslam medeniyeti doğuşu ile birlikte büyük bir yenilik ve tazelik getirmiştir. Hakkın Sesleri kitabında Âl-i İmran sûresinin 110. Âyetinden ilhamla yazdığ 1 manzumede bu düşünceler açıkça dile getirilir. Şaire göre "Kapkaranlıkken bütün âfâkı insâniyyetin," İslam "Nûr olup fişkırmış"tır " tâ sinesinden zulmetin" ve "fetretten kalan yeldâları" yararak, "Fikr-i ferdâ doğmadan" Müslümanlar insanlık âlemine "ferdâları" yağdırmıştır. Şaire göre, yirmi beş yıllık Hz. Muhammed döneminde, sanki yirmi beş bin yıllık yenilenme ve tazelenme olmuşçasına verimli bir aydınlanma gerçekleşmiş; bu aydınlanma âlemi baştan ayağa uyandıracak şekilde kalıcı olmuştur. Din, ahlak, iman, adalet, ihsan gibi medeniyetin en önemli unsurları İslam peygamberinin yirmi beş yıllık döneminde toplumları bölük bölük sarmış, bütün bu toplumlar "vahdetin âheng-i cûşâ-cûşu$n a$ " dalmıştır. Bu dönemde fenalık, kötülük yerini tamamen iyilik ve güzelliğe bırakmış, hiç kimse bilerek ve isteyerek haksızlık yapma gafletine düşmemiştir. ${ }^{18}$

Görüldüğü üzere Âkif, irfan, aydınlanma, düşünce, din, ahlak, adalet, birlik ve uyum gibi bir medeniyetin hem maddi hem de manevi unsurlarını sayarak İslam peygamberinin yirmi beş yıllık peygamberliği döneminde İslam'ın bu nitelikleriyle büyük bir mesafe kat ettiğini, toplumlara örnek olduğunu dile getirmektedir. Bu bağlamda Hz. Muhammed, sadece bir elçi olarak ya da kendisinden şefaat beklenen klasik anlatıyla değil, bir medeniyet kurucu sembolü olarak da idealize edilmekte, şiir diliyle bu noktada bir bellek tazelenmesine çalışılmaktadır. Hemen belirtmek gerekir ki, Âkif bu hususa sadece şiirlerinde değil, düzyaz1larında da değinirek, Hz. Muhammed'in İslam medeniyetinin vücut bulmasındaki kurucu rolü üzerinde durur. ${ }^{19}$

17 Mehmed Âkif Ersoy, Safahat, Ankara, Akçă̆ Yayınları, 2008, s. 510.

18 a.e., s. 238.

19 “Âkif, İslam'ın terakkiye mani olmadığını, geçmişte medeniyet dünyasına sayısız hizmetler ettiğini vurgular. Yusuf Suresi 153. Ayetin tefsirinde bir Batılının ağzından Müslümanların İslam'ın doğuşundan sonraki iki asır içinde insanlık âlemine sayısız astronomi âlimi yetiştirdiğini aktarır. Bunu söyleyen Batılı şahsiyet kilisenin, hâkimiyetinde geçen on iki asra rağmen bir astronomi âlimi bile çıkaramadığını belirttiğini aktarır. Âkif, bir başka yazısında da Müslümanların asr-1 saadet yıllarında ilim ve fen sahasında gösterdiği ilerlemeyi anlatır. Âkif, o dönem sahip olunan ilim ve fennin Frenklerin de dikkatini çektiğini ve tahsil için Avrupa'dan Bağdat'a geldiklerini aktarır. Endülüs medreselerinde birçok papazın ve kralın da okuduğunu söyler.” Bkz.: Mehmed Âkif Ersoy, Düzyazılar: Makaleler, Tefsirler, Vaazlar, (Haz.: A. Vahap Akbaş), İstanbul, Beyan Yayınları, 2011, s. 325. 
Benzer bir yaklaşım Bir Gece şiirinde de görülür. Şair, kendi zamanından on dört asır evvel dünyaya gelen Hz. Muhammed'in, buhran içindeki dünyanın örtmesi yüzünden onu hissetmeyen ve görmeyen gözlere rağmen kırk yaşına geldikten sonra insanlığı kurtardığını söyler. Şaire göre Hz. Muhammed köhnemiş bir düzenden yepyeni bir düzen inşa etmiş, bu düzen insanlığa huzur ve mutluluk getirmiştir. İnsanların yırtıcılıkta sırtlanları geçtiği, kardeşin kardeşi yediği, anarşi ve kargaşanın yeryüzünü sardığ 1 , ayrılık salgınının Doğu'yu sardığı bir devirde kayserleri ve kisraları yere sererek, âcizin hayat bulduğu, zulmün yok olduğu, İslam kanunlarının hâkim olduğu ve böylece adaletin sağlandığı bir kurtuluş olur. $\mathrm{Bu}$ sebeple ferdi ve cemiyetiyle bütün bir insanlık ona borçludur. ${ }^{20}$

Mehmed Âkif'in Pek Hazîn Bir Mevlid Gecesi, Necid Çöllerinden Medîne'ye ve Bir Gece şiirlerinde de tema doğrudan Hz. Muhammed'dir. Şair, yukarıda bahsedilen şiirlerinde olduğu gibi adı geçen şiirlerde de İslam dünyasının ve Müslümanların hâli, Hz. Muhammed'in asr-1 saadet yıllarındaki kurucu rolü gibi kendi çağını da kuracak yegâne şahsiyet oluşuna, Müslümanları birleştirip bütünleştirme gücüne ve buna olan ihtiyaca değinir. Bu bağlamda İslam peygamberini bütün nitelikleriyle kendi çağında yeniden bir şuur olarak diriltme davasındadır denebilir. Onun kurucu rolünü hâle taşıyarak bir bilinç oluşturmak isteği bu şiirlere de hâkimdir.

Pek Hazîn Bir Mevlid Gecesi şiirinde İslam peygamberine "Ylllar geçiyor ki, yâ Muhammed, / Aylar bize hep Muharrem oldu!" misralarıla şikayet eder bir eda ile başlayan şair, üç yüz elli milyonluk İslam âleminin bir matem havası içinde bulunduğunu, minarelerin suskun, şeriatın çiğnenmiş, mazlumların ezilmekte olduğunu dile getirir. Onun Hz. Muhammed'den istediği şefaat değil, istimdattır. "İslamı bırakma böyle bîkes, / İslamı bırakma böyle mazlûm." mısraları ile bitirdiği şiirin sonunda istimdata davetin de eşlik ettiği görülür. ${ }^{21} \mathrm{Bu}$ yönüyle, denebilir ki, Âkif, İslam medeniyetinin yeniden dirilip eski gücüne kavuşmasını Hz. Muhammed' in manevi varlığına bağlamaktadır. ${ }^{22} \mathrm{Bu}$ manevi varlığın Müslümanları aynı duygu ve şuurda birleştirmesinin somutlaştırılmış anlatısına ise Necid Çöllerinden Medîne'ye manzumesinde rastlanır. Şairin kendi peygamberine olan sevgi, saygı, haşyet ve muhabbet taşkınlığının yoğun olduğu bu manzumede, Medine'ye yapılan yolculuk, Hz. Muhammed'in kabrine vasıl oluş ve bu vuslatın uyandırdığı akisler anlatılır. Manzumenin özellikle son bölümü şairin İslam peygamberinin manevi birleştiriciliğine yaptı̆̆ 1 vurgu bakımından önemlidir. Kabrin önünde farklı milletlerden Müslümanlar aynı duygu ve hislerle bulunmakta, hiçbiri diğerini yadırgamamakta, aynı amaca yönelmekte, dudaklarında benzer duaları terennüm etmektedirler. Serendibli, Mağribli Hz. Muhammed'in kabri-

20 Mehmed Âkif Ersoy, Safahat, s. 513.

21 a.e., s. 244.

22 Benzer düşünceler için Bkz.: M. Fatih Andı, a.g.m., s. 42. 
nin önünde dua etmektedirler ve şair bu insanların dualarında istedikleri şeylere katılmamasının mümkün olmadığını, ümmet şuuru gereğince dile getirir. "Gerek bu âleme âid, gerekse âhirete,/ Ne istesin ki, beraberce ben de istemeyim?" diyen şair, farklı milletlerden Müslümanların her birinin ayrı ayrı kardeşi olduğunun altını çizer. Hz. Muhammed'in maneviyatı önündeki vahdetin yıkılmayacağını "Cihan yıkılsa bu vahdet yerinden oynar mı?" misraiyla vurgular. ${ }^{23}$

Denebilir ki, Mehmed Âkif, ideal olarak gördügü peygamber/asr-1saadet devri Müslüman kimliğini yeniden inşa etmek istemektedir. Bunun için İslam Peygamberi Hz. Muhammed'i -onun en yakın takipçileri olan halifeler ve sahibelerle birlikte- en önemli örnek olarak seçer. Onlara ait tarihi anekdotlar aktarır şiirlerinde ve düzyazılarında. Müslümanlığı doğrudan doğruya peygamberinden alan Müslümanları, İslami terminolojiyle söyleyecek olursak, "sahabeyi" örnek almanın önemine vurgu yapar. Onların yaşayışına dikkatle bakıldığında İ̀lam dininin ifrat ve tefritin her türlüsünden uzak olduğunun görüleceğini belirtir. Hz. Ömer'in dünyadan elini eteğini çekmiş bir kişiye öfkelenmesini örnek göstererek, dünyaya meyletmek ya da meyletmemek hususunda aşırıya kaçmanın yanlışlı̆̆ını ifade eder. ${ }^{24}$

Mehmed Akif'in İslam'ın ilk yıllarına dair verdiği örnekler genel olarak iki aktüel meseleye dair bir çözüm arayışından kaynaklanır: Birincisi Müslümanların birlik ve beraberlikten yoksun, dağınık ve atalete saplanmış halleridir. İkincisi ise âdil, sorumluluk bilinci yüksek, güvenilir hükümdar sorunudur. Âkif, Müslümanların yaşadığı sıkıntıların arka planında bu iki genel, aynı zamanda temel sorunun olduğuna inanır. Hz. Muhammed ve onun ardından gelen halifeler devrinin şan ve şeref dolu günlerinin yaşanmasında, ona göre adalet ve kardeşlik düsturu önemli olmuştur. Müslümanlar birbirlerini Peygamber etrafinda sık1 s1kıya kenetlendikleri için büyük bir medeniyet hızla kurulabilmiştir. Dolayısıyla Akif'te tarihi şahsiyet olarak Hz. Muhammed, bu iki temel düsturdaki eksiklerin nasıl giderileceğine dair bir argüman olarak çıkar ortaya. Hemen her güncel problemin çözümüne İslam peygamberini, devrini ve çevresindeki önemli şahsiyetleri örnek vererek yaklaşır. Bu bağlamda Hz. Muhammed, Âkif için sadece maddi varlığıly geçmişte İslam medeniyetinin şekillenmesinde ve gelişmesinde etkili olan bir şahsiyet değil, manevi varlığıyla her kendi devrinde ve sonraki devirlerde İslam medeniyetinin yeniden kurulmasını sağlayacak başat şahsiyet, bir başka deyişle bellektir.

Hz. Muhammed'in geleneksel edebiyat içinde anlatımından bu ilk sapma, Cumhuriyet dönemi şiirinde de devam etmiştir. Mehmed Âkif'ten sonra Arif Nihat Asya'nın kaleme aldığ 1 Naat başlıklı uzun şiiri gerek dili gerek anlatımı

23 Mehmed Âkif Ersoy, Safahat, s. 367.

24 Mehmed Âkif, Düzyazılar: Makaleler, Tefsirler, Vaazlar, s. 312. 
gerekse üslubu ve duygu yoğunluğu ile Türk edebiyatının naat geleneği içindeki yerini almıştır. Bununla birlikte Mehmed Âkif'in Hz. Muhammed'i şiirinin konusu yaparken ona yüklediği İslam medeniyetini "kurucu" ve "koruyucu" rolü Asya'nın Naat'ında eksiktir, bir başka deyişle onun kadar baskın değildir. Âkif'le birlikte başlayan hâlin kötü şartlarından sıyrılma, uzaklaşma ve sosyal, siyasi, ekonomik, ahlaki çözülme karşısında Hz. Muhammed'in "kurucu”luğuna ve "koruyucu" luğuna sığınma, onu bir önden, bir klavuz olarak görme tavrının Cumhuriyet döneminde Necip Fazıl Kısakürek ile devam ettiği söylenebilir. Kısakürek, Mehmed Âkif’ten farklı bir dil ve üslupla olmakla birlikte benzer hassasiyet ve kaygılarla yönelir İslam peygamberine. Ona göre Hz. Muhammed "Gaye insan ve ufuk Peygamber" dir. O, müstakil olarak Hz. Muhammed'in hayatını anlattı̆g 1 biri mensur diğeri manzum iki eser kaleme alarak, Cumhuriyet edebiyatında bu vadide eser veren ilk isim olmuştur demek yanlış olmaz. Çöle İnen Nûr, edebi dille kaleme alınmış bir mensur siyer çalışması olarak Türk edebiyatında başat bir eser olmuştur. ${ }^{25}$ Esselâm ise, manzum olarak Hz. Muhammed'in hayatını kronolojik şekilde anlattığ1, altmış üç bölümden meydana gelen bir eserdir ve geleneksel manzum siyer türünün modern Türk edebiyatı içindeki ilk örneği olmuştur.

Bütün bunların yanında Necip Fazıl'ın şiirlerini topladığı Çile adlı eseri içinde peygamber temalı şiirler önemli bir yekûn tutar. Birçoğu iki mısralık bu şiirlerde, Mehmed Âkif'le birlikte başlayan Hz. Muhammed'e hâlin sosyal, siyasi, ekonomik, ahlaki şartları içinden bakma anlayışı baskındır. "Kılavuz" olarak gördüğü ve bu yönüne birçok şiirinde vurgu yaptığı İslam peygamberi Necip Fazıl için aynı zamanda dünyadaki en büyük inkılabın da sahibidir. Düzyazılarında bu inkılaba erişmenin mümkün olmadığını, bu inkılabın ancak örnek alınabileceğine vurgu yapar. Ona göre bütün İslam âlemini insanlığa örnek bir devlet ve cemiyet haline getirmenin İslam peygamberinin inkılabının örnek alınmasıyla mümkün olacağına inanır. Bu inkılabı idealize etmekle kalmaz, bunun örnek alınması için çalışır, ideolocyasını temel üzerine örer. Onu aktüel zaman taşıma gayretini bizatihi dile getirir. ${ }^{26}$ Zira bu, ona göre örnek alınması zorunlu bir ink1laptır. "İnkılâp, bu ... İnsanı yeniden imâl eden bir inkılâp! Kalıbına yerleştirici inkılâp!.. Mutlak inkılâp..." der. ${ }^{27} \mathrm{~Hz}$. Muhammed'i "bağll olunacak akıl" olarak gösterir. ${ }^{28} \mathrm{~Hz}$. Muhammed onda tarihin de üstündedir. Zira kâinatın yaratılış gayesi olarak onu görür. İnsanoğlunun en olgun ve eksiksiz hali de odur Necip Fazıl'a göre. Bu yüzden insanın onun olgunluğuna ve eksiksizliğine ulaşmak gayretinde olması gerektiğine inanır. Bu yüceltme onu tavsif ediş şekline de akseder. "Gaye-İnsan ve Ufuk-Peygamber"

25 Necip Fazıl Kısakürek, Çöle İnen Nur, İstanbul Büyük Doğu Yayınları, 2006.

26 Necip Fazıl Kısakürek, Hesaplaşma, İstanbul, Büyük Doğu Yayınları, 2014, s. 57.

27 Necip Fazıl Kısakürek, Dünya Bir İnkllap Bekliyor, İstanbul, Büyük Doğu Yayınları, 2015, s. 23.

28 Necip Fazıl Kısakürek, Hesaplaşma, s. 77. 
dediği Hz. Muhammed'in, bütün zaman ve mekânın da peygamberi olduğu inancını taşır. Gidilmesi gereken yolun onun yolu olduğunu, kendi gittiği yolun da bu yol olduğunu belirtir. "Kül haline gelmiş eserler, kendini kaybediş ve bulamayış, tlkall yollar ve büyük kördüğüm" devrinde o gelmiş ve bütün düğümleri çözmüştür. ${ }^{29}$ Necip Fazıl'ın yegâne ink1lap olarak gördügüü de budur.

Bütün bunlar Âkif’te nüvelenen düşüncelerin bir nevi devamıdır. Bu devamın bilinçli bir takibin sonucu ispatı zor müşkül olmakla beraber aynı dünya görüşünün, aynı inancın, aynı hedef ve amaç birlikteliğinin bir tezahürü olarak ortaya çıktığı söylenebilir.

Necip Fazıl'ın peygamber sevgisinin ve onu yegâne k1lavuz olarak görmesinin örneklerine şiirlerinde de rastlanır. 1949 yılında yazdığ1 O'nun Ümmetinden Ol! Başlıklı şiirde bütün "serseri yol"ları, "hiçliğe bakan yön"leri, "arşı arayan sesler"i ve "hevenk hevenkinsanlık"1 bütün "çelik put"ları bırakıp doğrularak onun ümmeti olmaya çağırır. ${ }^{30}$ Sakarya Türküsü'nde ise "Sen kıvrll, ben gideyim, Son Peygamber Kılavuz!" diyerek cemiyetin arkasından gideceği şahsiyeti peygamber olarak işaret eder. Onun kendisine hayat gayesi edindiği, ideolojisini üzerine bina ettiği İslam dini, Hz. Muhammed'de müşahhaslaşmış, onun peygamberliğinde doğmuş, büyümüş ve yayılmıştır. Dolayısıyla Necip Fazıl, inandığı dinin peygamberine aşk derecesinde bağlıdır. Gayesi onun yolundan gitmek, onun ulaştığ kemale ulaşmak, onun getirdiği nizamı cemiyete yaymaktır. Bu nizam bütün kurum ve yapılarıyla İslam medeniyetidir demek yanlış olmaz. Bu bağlamda yol da varlık da onundur. Dolayısıyla hayatın düzeni, akışı, işleyişi ona/onun düzenine bağlıdır. Bu düzenin dışında olan her şey ona göre angaryadır. Son Siğınak şiirinde "Ey insan, sana son siğınak, / Son Peygamberin hirkasında!"'31 der. Hz. Muhammed, ona göre "Zaman ve mekân üstü biricik rejim, İslâm" 32 diyerek idealleştirdiği İslam dininin peygamberi, bu dini insanlara hayatıyla anlatan kişi olarak bayraklaşan şahsiyettir. Necip Fazıl'a göre varoluşun ve ölümsüzlüğün sırrı, iyiliğin mihenk taşı, tek doğru kanunun sahibi, zaman ve mekân üstü nizamın kurucusu, gerçek hürriyeti getiren kişi ve kalpten faniliği deviren devrimci Hz. Muhammed'dir. ${ }^{33}$ Onun vurguladığ en önemli husus olan varlığın Hz. Muhammed'e bağlı oluşu, hayata ait hemen her şeyin bu bağlılık oranında iyi ve kötü olmasıdır. Denebilir ki o da Mehmed Âkif gibi bir medeniyet perspektifinden bakar İslam peygamberine. Aralarındaki fark ise Mehmed Âkif'in somut ve eyleme dönük yaklaşımına karşın Necip Fazıl'ın fikir çerçevesi içinde yoğunlaşmasıdır.

29 Dünya Bir İnkılap Bekliyor, s. 61.

30 Necip Fazıl Kısakürek, Çile, İstanbul, Büyük Doğu Yayınları, 2015, s. 397.

31 a.e, s. 429.

32 a.e, s. 445.

33 a.e, s. $435-465$. 
Medeniyetin varlığından söz edilebilmesi için iki unsur olmazsa olmazdır. Bunlardan biri insan, diğeri ise toplumdur. Medeniyet insan varlığının bir toplum içinde ortaya çıkardığı her türlü maddi ve manevi ilerlemedir. Bu bağlamda Necip Faz1l, "Sende insan ve toplum, sende temel ve bina; / Ne getirdin, götürdün, bildirdinse âmennâ!..." ${ }^{34}$ mısraları ile İslam peygamberini açı şekilde medeniyet kurucusu olarak görmektedir. Zira insana ve topluma dair Hz. Muhammed'in getirdiklerini ve götürdüklerini kayıtsız şartsız onaylamaktadır. Burada Mehmed Âkif' in "Bir zamanlar bizde millet hem nasıl milletmişiz" mısraıyla başlayan şiiri ile Bir Gece şiirini hatırlamak gerekir. Bu iki şiirde de farklı üslup ve vokabüler bir yana Necip Fazıl'ın bakış açısının ilk örnekleri çok net olarak görülür. Burada "Ne getirdin, götürdün, bildirdinse âmennâ !" diyen şair başka bir şiirinde vurguyu bir adım daha kuvvetlendirerek "Müjdecim, Kurtarıcım, Efendim, peygamberim; / Sana uymayan ölçü, hayat olsa teperim!"35 diyerek, Hz. Muhammed'in getirdiği hayat nizamına uymayan bütün görüş, düşünce ve anlayışları reddedişini dile getirir. Necip Fazıl, tıpkı Âkif gibi Hz. Muhammed'i sadece İslam'ın ve onunla doğan ve gelişen İslam medeniyetinin kurucusu olarak değil, aynı zamanda kendi zamanında da manevi varlığı ve inanç mirasıyla kurtarıcısı ve kılavuzu olarak görür. İslam peygamberi, onda insandan topluma, toplumdan da varlığa giden çizgide tek bağdır. Bu çizgide insanın bütün varlığını Hz. Muhammed'e teslim etmesi gerektiğini "Gözüm, aklım, fikrim var deme, hepsini öldür! / Sana çöl gelen, $O$, göl diyorsa göldür!" ${ }^{36}$ misralarıla ifade eder.

İslam medeniyetinin köklerini Hazreti Âdem'e dayandıran Sezai Karakoç, bu medeniyetin sırasiyla bütün peygamberlerin elinden gelip Hazreti Muhammed'in Medine'de kurduğu İslam devleti ile son şeklini aldığına inanır. Ona göre İslam medeniyetinin asıl başlangıcı, Medine'de İslam devletinin kurulmasıdır ve ona göre bu bir devrimdir. Necip Fazıl'ın inkılap olarak gördüğü hadiseyi o devrim olarak görür. Bu devrimin hiçbir şeyi yıkmadığını, her şeyi yaptı̆̆ına inanır. $\mathrm{Bu}$ yapış esnasında bir buhran doğmamış, aksine her kurum anlam ve ruhça yenilenip tazelenerek, yeniden doğmuştur. ${ }^{37}$

İslam medeniyetinin bu hayat verici doğuşu ve gelişimi onun şiirine "bengisu” imajı olarak yansır. Bengisu, yani ölümsüzlük suyu... İslam medeniyeti tarih boyunca uğradığ 1 her coğrafyaya ve topluma ölümsüzlük suyu vermiştir ona göre. İlk insan ve ilk peygamber olduğuna inandığı Hz. Âdem'den itibaren, bütün peygamberler boyunca vermiştir bu ölümsüzlük suyunu üstelik İslam medeniyeti. Ama asıl çağlayanını Hz. Muhammed'le yakalamış ve asırlarca doğuda

34 a.e, s. 79.

35 a.e, s. 81.

36 a.e, s. 82.

37 Sezai Karakoç, İslâm Toplumunun Ekonomik Strüktürü, İstanbul, Diriliş Yayınları, 2015, s. 57. 
ve batıda, kuzeyde ve güneyde birçok coğrafyayı sulamıştır medeniyetinin ölümsüzlük suyuyla. Hızırla Kırk Saat'te İslam medeniyetinin bu tarihi dayanaklarına işaret edilir. ${ }^{38}$

Denebilir ki Karakoç İslam'ın bu ilk yıllarını yirminci yüzyıla eklemler. Bedir, Uhud, Hendek, Huneyn, Mekke savaşları ve fetihleri I. Dünya Savaşı'nda Müslümanların gösterdikleri mücadeleyle birlikte anar. Bedir'de sallanan kılıç Mekke'nin fethinde bir barış göstergesi olup, oradan Fırat ve Dicle havzasının fethinde görünürken, I. Dünya Savaşı'nda esir düşmüş bir askerin zihninde yaşar. "Babam düşünmüsstü bir vakitler Bedir'i / Hendek'i Uhut'u Huneyn 'i / Mekke'nin alınışını / Rusya'da esirken / Birinci Cihan Savaşı 'nda" diyen şair, İslam tarihinin bütün bu kurucu hadiselerini bir hafiza haline getirme, kendi zamanına taşıma ve yaşatma derdindedir. Bir dövme gibi vücudun ayrılmaz bir parçası haline getirilmesi derdindedir. Bunu "Bileğimizde Hayber'in döğmeleri / Yüzümüzde gülbeyaz Bedir demetleri / Saçımızdaki kına Hendek çiçekleri / Belimizde en sağlam kuşak / Mekke Fethi'nin kemeri" mısralarında ifade eder. ${ }^{39}$

Karakoç, Hz. Muhammed'den kendi zamanına kadar, İslam'ın her alanda "bilginler, erenler, şairler, sanatçılar, yöneticiler, askerler ve eşsiz bir halk" yetiştirmek suretiyle, tarihi pırıl pırıl aydınlattığını belirtir. Bu bağlamda İmam-1 Azam, İmam-1 Gazali, Muhyiddin İbn-i Arabi- Mevlana ve İmam-1 Rabbani onun

38 'Biz bir Hızır' $1 z$ ama belki bin Hizır gibi

Biliriz yeryüzünde bengisu illerini

Namazda yürüyoruz ışıldayan meşalelerle

Oruçta aydınlığız İsa’yla Meryem'le

Kulağımızda hep Zebur düğünleri

Düşümüzde İncil şölenleri

Ufkumuzda Tevrat ülkeleri

Sina dağından yapraklar

Ve Kur'an ordusunu

Başkentlere götüren bir kumandan gibi

En soy arap atının üstünde

Dimdik duran bir başkan gibi

Bengisu alayının önünde

Bir göçmen kuş öncüsüdür bengisu

...

Yusuf gömleğinin yıkandığı kaynak ondadır

Mısır'ın kapıları onunla açılır

Dâvud'un demirini eriten o

Karıncanın karnından konuşandır

Hüthüt onun üstünden yedi kere uçandır

$\cdots$

Bizse dirilişi gözlüyoruz

Bengisu bengisu kayna ve çağla" Bkz.: Sezai Karakoç, Gün Doğmadan, İstanbul, Diriliş Yayınları, 2010, s. 188-189.

39 a.e, s. $278-281$. 
İslam tarihinde ismini andığ 1 ve idealize ettiği isimlerdir. ${ }^{40}$ Bütün bu isimler ilhamlarını İslam'dan, dolayısıyla onun peygamberi olan Hz. Muhammed'den almışlardır.

Karakoç da Müslüman bir şahsiyet olarak İslam peygamberine bağlıdır ve onu eserlerinin başköşesine oturtur. Çeşitli vesilelerle onu anar, ona göndermelerde bulunur. Hz. Muhammed, onda da başlı başına bir örnek, bir sembol ve ideal şahsiyettir. Hz. Muhammed'in gelişiyle zaman dirilmiş, gidişiyle de zaman ölmüş gibi olmuştur. O, Kâbe'yi putlardan temizlemekte kalmamış, "kalplerdeki ve düşüncelerdeki, hayallerdeki ve hülyalardaki putlarl" kırmıştır. Irkçılığ1 ve köleliği bitirmiş, iyilik ile kötülük arasındaki sınırları netleştirmiş, insanı varoluşuyla ilgili bütün sorulardan ve bunalımlardan kurtarmıştır. Onu bütün nitelikleri, getirdikleri, yaptıkları, söyledikleri ile bir mucize olarak ifade eder. ${ }^{41}$

Karakoç'a göre Hz. Muhammed, insanı cehalet ve zulüm karanlığından kurtarmış, bir inancın ışığıyla aydınlatmış, bütün güzellikleri yavaş yavaş yaymıştır. İnsanları putların ve insanların köleliğinden kurtarmış ve kendi fitratındaki özgürlüğe kavuşturmuştur. Hikmet ve mucize, onun sosyal yara haline gelmiş, kalıplaşmış bütün gelenekleri yıkmasının yegâne k1lıcı olmuştur. ${ }^{42}$ Bütün bu nitelikleriyle Hz. Muhammed, Karakoç'a göre gençliğe ve bütün insanlığa örnek olarak gösterilmesi gereken bir şahsiyettir. Bunu kendine bir ödev olarak gördüğü gibi bütün Müslümanlara da bir ödev olarak gösterir.

İslam peygamberi ve onun halifeleri devlet yöneticiliği bakımından da idealize edilir. Hz. Muhammed'in vahiy gelmeyen konularda karar vermeden önce çevresindeki insanlara danışması, bir nevi meclis oluşturması, insanları robot ya da otomat olarak görmemesi, herkesin fikrine saygı göstermesi ve önem vermesi, fikir özgürlüğüne müsaade etmesi idealize edilen hususlardandır. Ondan sonra gelen halifeler de onu takip etmişler, istişareye, meşverete önem vermişlerdir. Hz. Ömer, adaletiyle ve sosyal devlet anlayışıyla ayrı bir yer edinmiş, anıt bir örnek olmuştur. Sonraki dönemlerin İslam devletleri de daima peygamberin izlediği yolu takip etmişler, meşveretten, adaletten, yerine göre savaşçı, yerine göre barışç1 olmaktan, sosyal adaleti gözetmekten geri durmamışlardır ona göre. ${ }^{43}$

Hz. Muhammed'in mucizelerine, seçilmiş ve zamanlar üzeri oluşuna, buna bağlı olarak aktüel zamana etki etmesine vurgu yapar. Karakoç, onu geçmişin, kendi zamanının ve geleceğin yol göstericisi, yön tayin edicisi olarak görür ve şiirlerinde de bu duruma gönderme yapar. Bu bağlamda Hz. Muhammed'in Me-

40 Sezai Karakoç, Fizikötesi Açısından Ufuklar ve Daha Ötesi III, İstanbul, Diriliş Yayınları, 2013, s. 26-27.

41 Sezai Karakoç, Günlük Yazılar II - Sütun, İstanbul, Diriliş Yayınları, 2015, s. 416-417.

42 a.e., s. $418-420$.

43 Sezai Karakoç, Yapı Taşları ve Kaderimizin Çă̆rısı I, İstanbul, Diriliş Yayınları, 2014, s. 74-75. 
dine'ye gidiş yolculuğu, Medine'ye ulaşması, Bedir, Uhud ve Hendek savaşları, Mekke'nin fethedilmesi, son hutbesi ve vefatı bunlardan bazılarıdır. Örneğin $\mathrm{Hl}$ zırla Kırk Saat şiirinin 24. bölümünde "Dört kitap durdu ve dinledi / "Şahit ol ya Rab!" / Sesi kald c yalnız ortada" mısralarıyla veda hutbesine gönderme yapılır..4 Aynı şiirin 31. bölümünde Hz. Muhammed'in Medine'ye hicret etmesi esnasında mağaraya sığınması ve mağaranın örümcek ağı ve güvercin yuvası ile korunması hadisesine "Ey bir aydır / Örümcek ă̆l gibi ipekten / Düsser bir kuş tüneğinden" misralarıyla gönderme yapılır. Ayrıca dolunayı ortadan ikiye bölme hadisesine de "Ey ay bölün ey dolunay bölün / Doğudan batıdan / Birden görün / Sana okuduğumu anladınsa" mısralarıyla temas edilir. ${ }^{45}$ Bunlarla birlikte aynı şiirin 32. bölümünde ise "Kudüs te / Hazırlandı kaya / Yerden yükselmeye bir parça" mıralarıyla Miraç hadisesine; 33. bölümünde ise "Sütunlar çökse ne dersiniz / Save gölü kurusa / Ne dersiniz / Sönmez ateşs sönse" misralarıla Hz. Muhammed'in doğumuna gönderme yapar. ${ }^{46}$

Karakoç'a göre Hz. Muhammed, insanlığın bütün yaralarını iyi edecek, bütün insanlık hastalıklarına iyi gelecek yegâne şahsiyettir. O kendi zamanında İslam coğrafyasının ihtiyaç duyduğu dirilişe ilham verecek, onu gerçekleştirecek ruhta yaşayacak olan yegâne insandır. İlk iki ismin birbirinden üslup ve vokabüler olarak ayrılması gibi Karakoç da bu yönüyle onlardan ayrılır ve çağrışımı bol bir şiir dili ile anlatır Hz. Muhammed'i şiirlerinde. Karakoç'un şiirlerinde İslam peygamberine, zengin bir çağrışım içinde değinilir. $\mathrm{O}$, medeniyetin sembolüdür. "Gelin gülle başlayalım atalara uyarak" derken "gül" sadece İslam peygamberi değil, aynı zamanda İslam medeniyetidir. Mehmed Âkif'ten de Necip Fazıl'dan da daha yoğun ve açık (gösteren gösterilen ilişkisi bakımından açık) olarak Hz. Muhammed ile İslam medeniyeti örtüştürülür Karakoç’ta. Bununla birlikte ilk iki isimle çok benzer söylemleri de vardır şiirinde. Örneğin "Kalk ey / Örtülere bürünmüş Peygamber / Bu sitmayla iyi edeceksin / Tifolarl vebalarl / İnsanlığl kâğıt kâğıtt/ Buruştran cüzzamı" ${ }^{47}$ misraları yukarıda bahsedilen, Âkif'in İslam peygamberinin gelişiyle ortaya çıkardığını söylediği aydınlığa ve yok ettiği karanlığa; Kısakürek'in İslam peygamberinin getirdip götürdüğü her şeye "âmen$n \hat{a}$ " diyerek onaylamasina benzemektedir.

Karakoç, şiirinde Hz. Muhammed'in İslam medeniyetini kurucu rolünün yanı sıra, onu yeniden diriltecek güç olmasına da kendinden önceki iki şairde olduğu gibi, fakat onlardan daha baskın şekilde işaret eder. "Çan sarasını /Havra harmanını /Gögüule gönenen Harran’ı /Çile çömleği İskenderiye'yi” diriltecek olan da "Cennetlerden çağlayan/ Nil'in Firat'in Dicle'nin" suyunu arıtacak olan da

44 Gün Doğmadan, s. 229.

45 Gün Doğmadan, s. 249.

46 Gün Doğmadan, s. 261, 266.

47 a.e., s. 276. 
"Seher çocuklarının/ Tek kentini" kuracak olan da "Dünya geldi geleli / En önemli haberi" bildirecek olan da Hz. Muhammed'dir Karakoç'a göre. ${ }^{48}$ Dolayısıyla kuruluşun da dirilişin de kaynağı İslam peygamberidir ona göre.

Karakoç, Hz. Muhammed'e dair bu hissiyat ve düşüncelerle Küçük Na't adlı bir şiir kaleme alır ve bu şiirde Mehmed Âkif'le başlayıp Necip Fazıl'la derinleşen Hz. Muhammed'e fikri teslimiyet ve onu bir bellek haline getirme çizgisini sürdürür. "Göz seni görmeli ă̆ız seni söylemeli / Hafiza seni anmak ödevinde mi" mısralarıyla şiire başlayan şair, Hz. Muhammed'in bir bellek olarak taşınması zorunluluğuna "ödev" vurgusuyla işaret eder. Burada İslam peygamberinin hafıza olması salt şahsiyetinin hatırlanması değil, bütün bir eserleri bağlamında düşünüldügünde kurucusu olduğu İslam medeniyetinin maddi ve manevi değerler bütünü ile birlikte hatırlanması, bir bellek olarak taşınmasıdır. Şiirin devamındaki "Sen Eskimoların ısınması sevgililer mahşeri" mısraıysa iki şekilde yorumlanabilir: İlki peygambere olan sevginin ve muhabbetin donuk kalpleri bile 1sındırmasıdır. İkincisi ise Eskimolar gibi medeni gelişmişlikten doğal zorunluluklar gereği uzak yaşayan, herhangi bir medeniyet ilerlemesi gösteremeyen toplumların bile $\mathrm{Hz}$. Muhammed ile medeniyete kavuşmalarıdır. $\mathrm{Bu}$, aşırı bir yorum gibi gelse de sonraki bölümde şairin içinde Nuh'un en yeni tufanının bulunduğunu belirtmesi ve dünyaya yeniden ayak basmaktan bahsetmesi ile birlikte düşünüldüğünde çıkarsama daha sağlam bir temele oturmaktadır. Zira hem Nuh Tufanı ile dünyaya yeniden ayak basma vurguları, yeni bir medeniyet başlangıcına, medeniyetin yeniden kurulmaya başlanmasına, bir medeniyet dirilmesine işaret etmektedir. "Ben yeni doğmuş bir çocuk gibi / Herkesin konuştuğu dilden mahrum / Ama yepyeni bir dil konuşmanın sevinci" misralarında İslam peygamberi ile gelen inancın ve bu inancın doğurduğu hayat nizamının farklılı$\breve{g} 1$, tazeliği, masumluğu vurgulanmaktadır ki, İslam medeniyetinin ilk devirlerine dair Mehmed Âkif ve Necip Fazıl Kısakürek'in düşünceleri hatırlanmalıdır burada. Zira onlar da İslam medeniyetinin ilk yıllarının bütün insanlığa yeni bir soluk getirmesine, kötülükleri yok etmesine, bir ink1lap olma özelliklerine vurgu yapmışlardır. Şiirin sonuna doğru yollardaki zafer taklarından, eriyen karlardan bahseden şair, "Gün doğuyor her yer çiçek ve kar / Bütün çocuklar kurtuldu demektir" misralarıla İslam peygamberinin yenileyici, tazeleyici ve diriltici etkisine gönderme yapmaktadır şair. ${ }^{49}$ Mehmed Âkif'in, gelişiyle yarınlar aydınlattığını söylediği, Necip Fazıl'ın getirdiği ve götürdüğü her şeye âmenna dediği ve en büyük inkılabın sahibi olarak gördüğü Hz. Muhammed, Sezai Karakoç tarafından da İslam medeniyetinin dirilişinin, hayat buluşunun sembolü olarak gösterilir. 


\section{Sonuç}

Mehmed Âkif Ersoy, Necip Fazıl Kısakürek ve Sezai Karakoç, aralarında nesil farkı, şiir dili farkı, sosyal-siyasi-ekonomik şartların doğurduğu hayat farkı olmasına karşın aynı inancın ve dünya görüşünün, aynı mefkûrenin Türk düşünce ve edebiyatındaki başat isimleridir. Kimi araştırmacıların "İslamcı" olarak nitelediği bu isimler, yaşadıkları dönemde düşünce ve sanat hayatı üzerinde kuvvetli etkileri olmuş, kendilerinden sonraki nesilleri de etkilemiş, şekillendirmiş şahsiyetlerdir. İslam inancının ve buna bağlı dünya görüşünün bütün unsurları ile içtimai, iktisadi, siyasi ve hukuki alanlarda kendine yer edinmesi için mücadele vermiş bu isimler, inançlarına bağlı dünya görüşlerinden kaynaklanan ve bu yönüyle onları farklı kılan bir coğrafya, tarih ve medeniyet anlayışına sahiplerdir. Bu üç unsurdan medeniyetin, devletin resmi ideolojisine bağlı olarak Batı medeniyeti anlayışı çerçevesinde değer bulduğu yıllarda, İslam medeniyetinin hatırlanmas1, bir bellek olarak yirmi birinci yüz yıla taşınması konusunda, resmi kanonun dışında bir yol izlemişler, düşünce ve sanat eserleri ile bu mücadeleyi yürütmüşlerdir. Bu bağlamda onların şiirlerinin önemli bir motifi de İslam dininin peygamberi olmakla İslam medeniyetinin de en önemli simgesi olan Hz. Muhammed olmuştur. Geleneksel edebiyat ve şiir geleneğinin yaklaşımından farklı olarak, yirminci yüzyılın başında ilk olarak Mehmed Âkif Ersoy, Hz. Muhammed'e şiirlerinde gelenekten farklı olarak yönelmiştir. O, İslam ümmetinin içinde düştüğü ve yıllarca çıkamadığı yenilmişliği, tükenmişliği, zilleti, hüznü yedeğine alarak İslam peygamberine yönelir ve ona önce içinde bulunulan durumu şikâyet eder. Bu şikâyet istimdat ve davetle devam eder. İçinde bulunulan hâlden İslam'ın Hz. Muhammed'in de hayatta bulunduğu ilk yıllarına sığınma şaire bir teselli verir. Daha sonra da o büyük medeniyetin filizlendiği yılların mimarı olan İslam peygamberini manevi varlığı ile hâle davet eder. İslam medeniyetinin yeniden silkinip kendine gelmesi Hz. Muhammed'in yolundan gitmek, onu hatırlamaktır.

Bu tutumun bir devamı olarak Necip Fazıl Kısakürek şiirlerinde önemli bir motif olarak Hz. Muhammed'e yer verir. "Gaye insan ve ufuk Peygamber" olarak nitelediği İslam peygamberi, onun şiirlerinde her şeyiyle bir hayat rehberi, bir kılavuzdur. Şair, kurtuluşun, düzelişin o kılavuza uymakla mümkün olacağı inancındadır ve kendi ideolojisinde de kemikleşmiş olan bu düşünceyi, şiirinde işler. İnsan, toplum ve varlık Hz. Muhammed'e bağlıdır. Düzen onunla kaimdir. Ona uymayan hangi ölçü olursa olsun reddedilmelidir. Bu bağlamda Necip Fazıl, Mehmed Âkif'ten farklı bir vokabüler, üslup ve tarzda Hz. Muhammed'in medeniyet kurucu rolüne zaman ve mekân üstü olarak işaret eder.

Sezai Karakoç ise İslam'ı bizatihi medeniyet olarak gören, İslam medeniyetini İslam dini anlamında kullanan bir şahsiyet olarak bu medeniyetin en önemli sembolü olarak Hz. Muhammed'i görür. İslam kentinin kurucusu, bütün hastalıkların iyi edicisi, dirilişin müjdecisi olarak İslam peygamberini işaret eder. İlk 
iki isimden dil ve üslup bakımından tamamen farklı olmakla birlikte benzer göndermeler yapan Karakoç, Hz. Muhammed'i Hz. Âdem'den kendi zamanına ve oradan da bütün zamanlara İslam medeniyetinin yegâne taşıyıcısı olarak görür. O, hikmet ve mucizesiyle İslam medeniyetinin kurulmasını ve güçlenmesini sağlamış, sadece Kâbe'deki değil, kalplerde, düşüncelerde ve hayallerdeki putları da yıkmış, bütün donmuş kalpleri Eskimoların 1sınması gibi 1sıtarak İslam medeniyetine kavuşturmuştur. Gençliğe ve bütün insanllğa örnek en büyük örnektir. Göz onu görmelidir, ağız onu söylemelidir ve hafıza onu anmalıdır. Böyle olursa İslam medeniyeti yeniden dirilecektir.

Denebilir ki, her üç isim de Hz. Muhammed'i İslam medeniyetinin yeniden dirilmesi için en önemli şart olarak görmekte, onun kurucu rolüne vurgu yapmakta ve bu niteliklerini bir "bellek" olarak gelecek nesillere şiirleri yoluyla aktarma gayretindedirler. 


\section{Kaynakça}

And1, M. Fatih, "Peygamber'i Şiirle Sevmek-XII: Hazret-i Peygamber'den İstimdâd", İtibar Aylık Edebiyat ve Fikir Dergisi, yıl 6, say1 53, Şubat 2016.

Ar1, Ahmet, Dîvân Edebiyatında Hazret-i Peygamber, http://www.sonpeygamber.info/downloads/uploads/kutludogum/I/19.pdf (10.09.2016, 19.00).

Braudel, Fernand, Uygarlıkların Grameri, çev. M. Ali Kılıçbay, Ankara, İmge Kitabevi, 2014.

Çelebioğlu, Âmil, “Türk Edebiyatında Manzum Dînî Eserler”, Şükrü Elçin Armağanı, Ankara, Hacettepe Üniversitesi Edebiyat Fakültesi, 1983.

Durant, Will, Medeniyetin Temelleri, çev. Nejat Muallimoğlu, İstanbul, Erguvan Yayınevi, 2007.

Ersoy, Mehmed Âkif, Düzyazılar: Makaleler, Tefsirler, Vaazlar, haz. A. Vahap Akbaş, İstanbul, Beyan Yayınları, 2011.

, “Leyle-i Mevlidü'n-Nebî Aleyhisselâm”, Strât-ı Müstakîm, c. 4, say1 81, 12 Rebîülevvel 328 (24 Mart 1910).

, "Leyle-i Mevlidü'n-Nebî Sallallahu Aleyhi ve Sellem”, Sirât-ı Müstakîm, c. 6, say1 132, 14 Rebîülevvel (16 Mart 1911).

, Safahat, Ankara, Akçağ Yayınları, 2008.

Kalın, İbrahim, "Dünya Görüşü, Varlık Tasavvuru ve Düzen Fikri: Medeniyet Kavramına Giriş”, Divan Dergisi, sayı 29, 2010.

Karakoç, Sezai, Gün Doğmadan, İstanbul, Diriliş Yayınları, 2010.

, Günlük Yazılar II - Sütun, İstanbul, Diriliş Yayınları, 2015.

Yayınlar1, 2013.

, Fizikötesi Açısından Ufuklar ve Daha Ötesi III, İstanbul, Diriliş̧ 2015.

, İslâm Toplumunun Ekonomik Strüktürü, İstanbul, Diriliş Yayınları, , Yapı Taşları ve Kaderimizin Çağrısı I, İstanbul, Diriliş Yayınları, 2014.

Karataş, Turan, Doğunun Yedinci Oğlu Sezai Karakoç, İstanbul, Kaynak Kitaplı̆̆ $1,2013$.

Kısakürek, Necip Fazıl, Çile, İstanbul, Büyük Doğu Yayınları, 2015.

, Çöle İnen Nur, İstanbul, Büyük Doğu Yayınları, 2006.

, Dünya Bir İnklap Bekliyor, İstanbul, Büyük Doğu Yayınları, 2015.

, Hesaplaşma, İstanbul, Büyük Doğu Yayınları, 2014. 